\title{
PROBIOTIC PROPERTIES OF ANTIMICROBIAL-PRODUCING LACTIC ACID BACTERIA ISOLATED FROM DAIRY PRODUCTS AND RAW MILK OF SABAH (NORTHERN BORNEO), MALAYSIA
}

\author{
MELISA ELSIE KASIMIN ${ }^{1}$, AINOL AZIFA MOHD. FAIK ${ }^{1}$, JAEYRES JANI ${ }^{2}$, SAHAR ABBASILIASI $^{3}$, \\ ARBAKARIYA B. ARIFF ${ }^{4,5}$ and ROSLINA JAWAN ${ }^{1,4^{*}}$ \\ ${ }^{1}$ Biotechnology Programme, Faculty of Science and Natural Resources, Universiti Malaysia Sabah, \\ Jalan UMS, 88400 Kota Kinabalu, Sabah \\ ${ }^{2}$ Borneo Medical and Health Research Centre, Faculty of Medicine and Health Sciences, \\ Universiti Malaysia Sabah, Jalan UMS, 88400 Kota Kinabalu, Sabah \\ ${ }^{3}$ Halal Products Research Institute, Universiti Putra Malaysia, 43400 UPM Serdang, \\ Selangor, Malaysia \\ ${ }^{4}$ Bioprocessing and Biomanufacturing Research Centre, \\ Faculty of Biotechnology and Biomolecular Sciences, Universiti Putra Malaysia, \\ 43400 UPM Serdang, Selangor, Malaysia \\ ${ }^{5}$ Department of Bioprocess Technology, Faculty of Biotechnology and Biomolecular Sciences, \\ Universiti Putra Malaysia, 43400 UPM Serdang, Selangor, Malaysia \\ *E-mail: roslinaj@ums.edu.my
}

Accepted 26 August 2020, Published online 25 October 2020

\begin{abstract}
This study aims to evaluate the probiotic properties of the antimicrobial-producing lactic acid bacteria (LAB) isolated from cow and goat milk, and various types of cheese. The isolated strains were biochemically characterized by sequence of tests namely Gram staining, catalase test and carbon fermentation. The agar well diffusion assay was performed by utilizing the Listeria monocytogenes ATCC 7644 and Listeria monocytogenes ATCC 13933 as the indicator microorganisms prior to biochemical and physiological tests to assess the beneficial properties of the strains. Results showed that 5 out of 20 isolated LAB strains were the antimicrobial-producer indicated by the formation of inhibition zones against the L. monocytogenes ATCC 7644 and L. monocytogenes ATCC 13933. All five strains were able to utilize glucose, and also tolerate various concentrations of $\mathrm{NaCl}$ and wide range of temperatures. Strains $\mathrm{CCB} 1, \mathrm{~GB} 3$ and $\mathrm{CB} 3$ showed positive proteolytic activity, while CCB1, GB3 and CA1 were able to hydrolyse starch. Other than that, isolates CCB1, CB3 and CA1 showed ability to deconjugate bile salt in both aerobic and anaerobic conditions. Moreover, CCB1, GB3 and CA4 were susceptible to ampicillin, tetracycline, ceftriaxone, penicillin $\mathrm{G}$ and chloramphenicol. However, most of the strains were resistant to norfloxacin, amikacin, colistin sulphate, streptomycin and nalidixic acid. Lastly, all of the five isolates were tolerant to bile salt and phenol as no growth inhibition was observed. The newly isolated LAB strains with valuable features might offer an unfolded potency that are beneficial for applications in food industry.
\end{abstract}

Key words: Isolation, lactic acid bacteria, food industry, milk products

\section{INTRODUCTION}

The rising awareness among the consumers on probiotics is expected to drive the industry growth over the next few years. The application of probiotic products is important in maintaining one's health as well as to cure gut-associated diseases such as bowel disease, lactose intolerance, indigestion and

* To whom correspondence should be addressed. diarrhea (Nazir et al., 2018). Nowadays, probiotics are widely used as health food and medicines in Asia and Europe, which subsequently increases the demand of these probiotic sources. Lactic acid bacteria (LAB) such as Lactobacillus, Streptococcus and Bifidobacterium species that commonly found in digestive system of human act as the main bacteria used as probiotics. LAB are Gram-positive bacteria, non-spore forming, catalase negative, and widely present in nature. LAB refer to a large group 
of good bacteria that are selected as probiotic due to the ability to promote human gastrointestinal health. Today, a wide variety of fermented milk products including yogurt and cheese, take benefits of these LAB applications (Linares et al., 2017). As LAB are recognized as safe (GRAS), where it is safe to be consumed by human without causing side effects, it has been widely applied in food industry due to the production of organic acids, such as lactic acid which results in lowered $\mathrm{pH}$ value (Gemechu, 2015) and also by producing antimicrobial substances known as bacteriocins (Perez et al., 2014). Many bacteriocins are active against foodborne pathogens such as Listeria monocytogenes, Escherichia coli, Campylobacter jejuni, Yersinia enterocolitica and Vibrio parahemolyticus (Altuntas, 2013). In recent years, due to the applications as safe additives in food preservation, bacteriocin producing LAB have become significant. Bacteriocin possess a lot of potential applications such as extending the time for food preservation which could be beneficial for the food industry, treatment of pathogen disease, maintaining human health and cancer therapy (Yang et al., 2014). Many studies have been reported on LAB isolation from dairy products, however, in Malaysia it is not yet been well studied especially in Sabah. Therefore, this study aimed to highlight the searching of potential antimicrobial-producing LAB from dairy products and raw milk of Sabah (Northern Borneo) for food applications.

\section{MATERIALS AND METHODS}

\section{Sample preparation and isolation of lactic acid bacteria}

Various types of cheeses (cow cheese, goat cheese and mozzarella) were obtained from the Desa Dairy Farm in Mesilau, Kundasang, Sabah while the raw milk (cow and goat milk) samples were collected from Department of Veterinary Services, Keningau, Sabah. The sample was stored at $4{ }^{\circ} \mathrm{C}$ until used. The milk samples were homogenized by gentle shaking. About $10 \mathrm{~mL}$ of milk sample and $4 \mathrm{~g}$ cheese sample were taken aseptically then, mixed with $90 \mathrm{~mL}$ de Man Rogosa Sharpe (MRS) and M17 broth, respectively and were incubated at $37^{\circ} \mathrm{C}$ for $24 \mathrm{~h}$. After the incubation, 10 -fold of serial dilution was performed. For the preparation of agar plates, the MRS and M17 agar were supplemented with $0.01 \%(\mathrm{w} / \mathrm{v})$ sodium azide to inhibit the growth of Gram-negative bacteria. About $100 \mu \mathrm{L}$ of diluted sample was spread on agar plates and incubated in anaerobic conditions at $37^{\circ} \mathrm{C}$ overnight. The higher dilution was used to perform the total counts. The colonies were chosen randomly and streak plating was performed two times to purify the strains on respective media either M17 or MRS media.

\section{Morphological, biochemical and physiological tests}

The morphology of the LAB was examined after the overnight incubation on MRS or M17 agar. The general procedures were used to carry out the Gram Staining, and the cell morphology was observed and examined by light microscopy. In catalase test, a drop of $3 \%(\mathrm{v} / \mathrm{v}) \mathrm{H}_{2} \mathrm{O}_{2}$ was spotted on the heavy colony of the LAB. A positive reaction will show immediate effervescence. To evaluate the ability of the strains to ferment carbon, nutrient agar with $1 \%$ $(\mathrm{w} / \mathrm{v})$ of glucose and $0.004 \%(\mathrm{w} / \mathrm{v})$ bromocresol purple (Sigma, United Kingdom) (as a $\mathrm{pH}$ indicator) was prepared. Then, about $10 \mu \mathrm{L}$ of the culture was dotted on the surface of the agar. The acid production can be indicated by the production of yellow zone around the culture after $24 \mathrm{~h}$ incubation at $37^{\circ} \mathrm{C}$.

\section{Identification of isolates by16S rRNA sequencing and phylogenetic analysis \\ Extraction of DNA and sequencing of the} amplified fragments were carried out according to methods of Reysenbach et al. (2000). Briefly, the bacterial 16S rDNA, full-length $1.5 \mathrm{~kb}$, was amplified using universal primers $27 \mathrm{~F}$ and $1492 \mathrm{R}$. The total reaction volume of $25 \mu \mathrm{L}$ contained genomic DNA purified using in-house extraction method, 0.3 pmol of each primer, deoxynucleotides triphosphates (dNTPs, $400 \mu \mathrm{M}$ each), 0.5U DNA Taq polymerase, supplied PCR buffer and deionised water. PCR was performed as follows: 1 cycle $\left(94^{\circ} \mathrm{C}\right.$ for $2 \mathrm{~min})$ followed by; 25 cycles $\left(98^{\circ} \mathrm{C}\right.$ for $10 \mathrm{sec}$; $53^{\circ} \mathrm{C}$ for $30 \mathrm{sec}$; $68^{\circ} \mathrm{C}$ for $1 \mathrm{~min}$ ) for annealing and extension of the amplified DNA. The PCR products were purified by standard method and directly sequenced with primers $785 \mathrm{~F}$ and $907 \mathrm{R}$ using BigDye ${ }^{\circledR}$ Terminator v3.1 Cycle Sequencing Kit (Applied Biosystems). The fragments of sequences were assembled and consensus sequences were compared with those deposited in the GenBank DNA database using the Basic Local Alignment Search Tool (BLAST; http://blast.ncbi.nlm.nih.gov/ Blast.cgi). A phylogenetic tree based on 16S rRNA 137 genes was constructed to determine the closest bacterial species by using Neighbour Joining (Unrooted Tree) by NCBI Blast Tree Method using Molecular Evolutionary Genetics Analysis (MEGA) software version 10.0.5 (Tamura et al., 2004). Distances and clustering with the NeighbourJoining method was determined using bootstrap values based on 1000 replications. Bacillus subtilis NCDO 1769 and Escherichia coli strain U 5/41 were 
used as an outgroup organism, respectively that serves as a reference group in evolutionary relationships determination of the ingroup.

\section{Effect of $\mathrm{NaCl}$ and temperatures on the growth of LAB}

About $1 \%(\mathrm{v} / \mathrm{v})$ of the bacterial cultures were inoculated into M17 or MRS broth containing different concentrations of $\mathrm{NaCl}(0.5,1.5,2.5,3.5$, $4.5 \%, \mathrm{w} / \mathrm{v})$ supplemented with $0.004 \%(\mathrm{w} / \mathrm{v})$ bromocresol purple and incubated at $37^{\circ} \mathrm{C}$. In temperature study, the isolates were inoculated into M17 or MRS broth containing $0.004 \%$ (w/v) bromocresol purple and was incubated at different temperatures $\left(-20,28,37\right.$ or $\left.70^{\circ} \mathrm{C}\right)$. The growth was evaluated which was indicated by the colour changes from purple to yellow after $48 \mathrm{~h}$ of incubation according to the method by Abbasiliasi et al. (2012).

\section{Effect of bile salts and phenol on the growth of LAB}

MRS broth containing $0.3 \%(\mathrm{w} / \mathrm{v})$ bile salts was inoculated with $1 \%(\mathrm{v} / \mathrm{v})$ of overnight culture and incubated in horizontal shaker for $4 \mathrm{~h}$ at $37^{\circ} \mathrm{C}$ and agitated at $100 \mathrm{rpm}$. The culture was harvested every hour by taking about $1 \mathrm{~mL}$ of sample culture. Pour plate method was performed to determine the growth of bacteria. Survival ability percentages of the LAB were calculated by comparing the growth $(\mathrm{CFU} / \mathrm{mL})$ at every hour with the number of viable cells at $0 \mathrm{hr}$. Phenol tolerance test was examined by taking $100 \mu \mathrm{L}$ of overnight culture into $100 \mathrm{~mL}$ of MRS broth containing different concentrations of phenol, which are $0.1,0.3$ and $0.5 \%(w / v)$. About $1 \mathrm{~mL}$ of the culture was taken at $0 \mathrm{hr}$ and $24 \mathrm{hr}$ to be used in pour plate method. The inhibition effect was determined by comparing the viable count $\left(\log _{10} \mathrm{CFU} / \mathrm{mL}\right)$ of LAB at $0 \mathrm{hr}$ and $24 \mathrm{hr}$.

\section{Acidification activity}

Acidification activity was determined by inoculating about $1 \%(\mathrm{v} / \mathrm{v})$ of bacterial strain into $10 \mathrm{~mL}$ of skimmed milk solution. The $\mathrm{pH}$ was measured at $0,24,48$ and $72 \mathrm{hr}$. The texture and smell of the milk were also recorded to evaluate the coagulation of milk.

\section{Starch hydrolysis test and Proteolytic activity}

Starch hydrolysis test was conducted by inoculating bacterial colony and streaking it on nutrient agar containing $2 \%(\mathrm{w} / \mathrm{v})$ of soluble starch powder. After overnight incubation, a small amount of iodine as indicating agent was poured on the surface of agar plate. A clear zone observed indicates positive reaction. The proteolytic activity was determined by inoculating the culture on nutrient agar supplemented with $1 \%(\mathrm{w} / \mathrm{v})$ of skim milk. The positive reaction (clear zones) was observed after $24 \mathrm{hr}$ of incubation.

\section{Bile salt deconjugation test}

The bacterial colony was inoculated on the surface of MRS agar supplemented with $0.5 \%(\mathrm{w} / \mathrm{v})$ taurodeoxycholate (TDC). The growth of strain was tested in both aerobic and anaerobic condition. The growth of colonies was observed after $24 \mathrm{hr}$ of incubation. The positive result is shown by the presence of precipitated bile acid around colonies (opaque halo).

\section{Antimicrobial activity test}

The antimicrobial activity of the isolated lactic acid bacteria was determined by using the agar diffusion method based on Abbasiliasi et al. (2012). Briefly, the isolate was grown in respective media either M17 or MRS broth and incubated at $37^{\circ} \mathrm{C}$ overnight. The culture was centrifuged at 10,000 $\mathrm{rpm}$ at $20 \mathrm{~min}$ at $4^{\circ} \mathrm{C}$. About $100 \mu \mathrm{L}$ of supernatant was placed into $6 \mathrm{~mm}$ wells of brain heart infusion (BHI) agar plates that were previously seeded with $1 \%(\mathrm{v} / \mathrm{v})$ of actively growing strain which is Listeria monocytogenes ATCC 7644 and L. monocytogenes ATCC 13933. The plate was incubated at $37^{\circ} \mathrm{C}$ for $24 \mathrm{hr}$ and the antimicrobial activity was determined by measuring the diameter of inhibition zones $(\mathrm{mm})$.

\section{Antibiotic sensitivity testing}

The susceptibility to antibiotic was determined by using the disc diffusion method according to Tagg et al. (1976). A single colony of LAB was inoculated into the respective broth (M17 or MRS broth) and incubated at $37^{\circ} \mathrm{C}$ for $24 \mathrm{hr}$. The bacteria were spread evenly on the surface of respective agar either M17 or MRS agar plate by using the sterile cotton wool swab dipped into the bacterial suspension. The antibiotics disc containing erythromycin $(10 \mu \mathrm{g})$, ampicillin $(25 \mu \mathrm{g})$, tetracycline $(10 \mu \mathrm{g})$, ceftriaxone $(30 \mu \mathrm{g})$, penicillin $\mathrm{G}$ (2 unit), chloramphenicol $(30 \mu \mathrm{g})$, norfloxacin $(10 \mu \mathrm{g})$, amikacin $(30 \mu \mathrm{g})$, colistin sulphate $(10 \mu \mathrm{g})$, streptomycin $(10 \mu \mathrm{g})$ and nalidixic acid $(30 \mu \mathrm{g})$ were gently placed on the surface of dried agar plates to ensure uniform contact between the disc and agar. The plate was incubated at $37^{\circ} \mathrm{C}$ overnight. The zones of growth inhibition around each of the antibiotic disc were measured (including the disc diameter) to the nearest millimetre. The isolates were classified as susceptible $(\geq 21 \mathrm{~mm})$, intermediate $(16-20 \mathrm{~mm})$, or resistant $(\leq 15 \mathrm{~mm})$ according to Abbasiliasi et al. (2012). 


\section{RESULTS}

Twenty lactic acid bacteria (LAB) strains were successfully isolated from various dairy products, raw goat milk and raw cow milk. Among these strains, five isolates namely CCB1, GB3, CB3, CA1 and CA4 were able to secrete antimicrobial substances as confirmed by their inhibition activity against Listeria monocytogenes ATCC 7644 and $L$. monocytogenes ATCC 13933 (Table 1). Therefore, all these five strains were further characterized to evaluate their probiotic potential. To evaluate the probiotics potential of $\mathrm{LAB}$, the tests involved were based on the parameters usually applied in food processing and human digestive system. Species identification was performed by $16 \mathrm{~S}$ rRNA gene sequencing. Analysis shown that the isolates CA1 and CA4 were highly similar and clustered together. Further analysis with the Average Nucleotide Index (ANI) was performed to check the correlation among the nearly clustered to evaluate the similarity (data not shown). Based on the ANI study the CA1 and CA4 was $100 \%$ ANI similar. The other near cluster group was 98.91\% [NR_044701 (Lactobacillus alimentarius)] and 99.31\% [NR_028949 (Lactobacillus mindensis)]. Meanwhile, the strains GC3 and CC3 were highly similar and also clustered together. CCB1 was slightly different as compared to $\mathrm{GC} 3$ and $\mathrm{CC} 3$. All the three strains were clustered with Enterococcus lactis strain F8, BT159, KH17, and $\mathrm{KC} 17$ (Figure 1).

The ability of isolates to grow at different concentrations of $\mathrm{NaCl}$ varied among strains. All the five strains were able to grow in MRS medium in the presence of $\mathrm{NaCl}$ up to $6.5 \%(\mathrm{w} / \mathrm{v})$ but were inhibited at $10 \%(\mathrm{w} / \mathrm{v})$. In temperature study, CCB1, $\mathrm{GB} 3$ and $\mathrm{CB} 3$ showed growth up to $70^{\circ} \mathrm{C}$, while $\mathrm{CA} 1$ and $\mathrm{CA} 4$ preferred low temperature $\left(-20^{\circ} \mathrm{C}\right)$ to grow (Table 2). The percentage of bacterial survivability in the presence of bile salt as shown in Figure 2. All five strains achieved the percentage of survival greater than $90 \%$ after $1 \mathrm{hr}$ incubation and continued to increase until $4 \mathrm{hr}$ of incubation indicating their tolerance towards bile salts. In addition, all of the selected strains were resistant to phenol at concentrations of $0.1,0.3$ and $0.5 \%(\mathrm{w} / \mathrm{v})$ (Table 3 ) and were able to acidity skim milk with $\mathrm{pH}$ reduction ranging between 4.6 to 5.1 (Table 4). Isolates CCB1, GB3 and CA1 were able to hydrolyse starch. Results also showed that most of the strains showed positive reaction in proteolytic activity with the exception of CA1 and CA4. For the bile salt deconjugation test, it was identified that $\mathrm{CCB} 1$ and $\mathrm{CB} 3$ were able to deconjugate TDC in aerobic and anaerobic conditions. No harmful effect of atmospheric oxygen was observed, as both strains were able to grow at aerobic condition. GB3 was only capable to grow in anaerobic condition while CA1 and CA4 did not grow in both conditions. Most of the strains were susceptible to ampicillin, tetracycline, ceftriaxone, penicillin $G$ and chloramphenicol but resistant to erythromycin, norfloxacin, amikacin, colistin sulphate, streptomycin and nalidixic acid (Table 5).

\section{DISCUSSION}

Lactic acid bacteria (LAB) are well known microorganism commonly found in dairy products especially in milk. In a study conducted by Masood et al. (2011), they revealed LAB found in goat milk possess the medicinal properties such as the ability to prevent colon and colorectal cancer. Alnakip et al. (2016) isolated several types of LAB and reported that the most predominant genus of $\mathrm{LAB}$ from the raw milk source is Enteroccocus sp. In this study, all the selected five isolates were able to secrete antimicrobial substance. The ability of the isolated strains to produce bacteriocin-like

Table 1. Morphological, biochemical characteristics and antimicrobial activity of LAB isolates

\begin{tabular}{lccccc}
\hline Characteristic & $\begin{array}{c}\text { Cow } \\
\text { cheese }\end{array}$ & Mozzarella & $\begin{array}{c}\text { Goat } \\
\text { cheese }\end{array}$ & $\begin{array}{c}\text { Cow } \\
\text { milk }\end{array}$ & $\begin{array}{l}\text { Goat } \\
\text { milk }\end{array}$ \\
\hline No. of LAB isolates & 3 & 1 & 1 & 8 & 7 \\
\hline $\begin{array}{l}\text { No. of isolates showing antimicrobial } \\
\begin{array}{l}\text { Activity against } L \text {. monocytogenes } \\
\text { ATC44/ ATCC13932 }\end{array}\end{array}$ & 1 (CCB1) & 0 & 0 & 3 (CA1, CA4, CB3) & 1 (GB3) \\
\hline $\begin{array}{l}\text { Cell morphology } \\
\text { Gram stain reaction }\end{array}$ & Cocci & Bacilli & Cocci & $\begin{array}{c}\text { Cocci (CA1, CA4) } \\
\text { Rod (CB3) }\end{array}$ & Cocci \\
\hline Catalase activity & + & + & + & + & + \\
\hline Glucose fermentation & - & - & - & + & + \\
\hline
\end{tabular}

Note: Positive reaction (+), negative reaction $(-)$. 


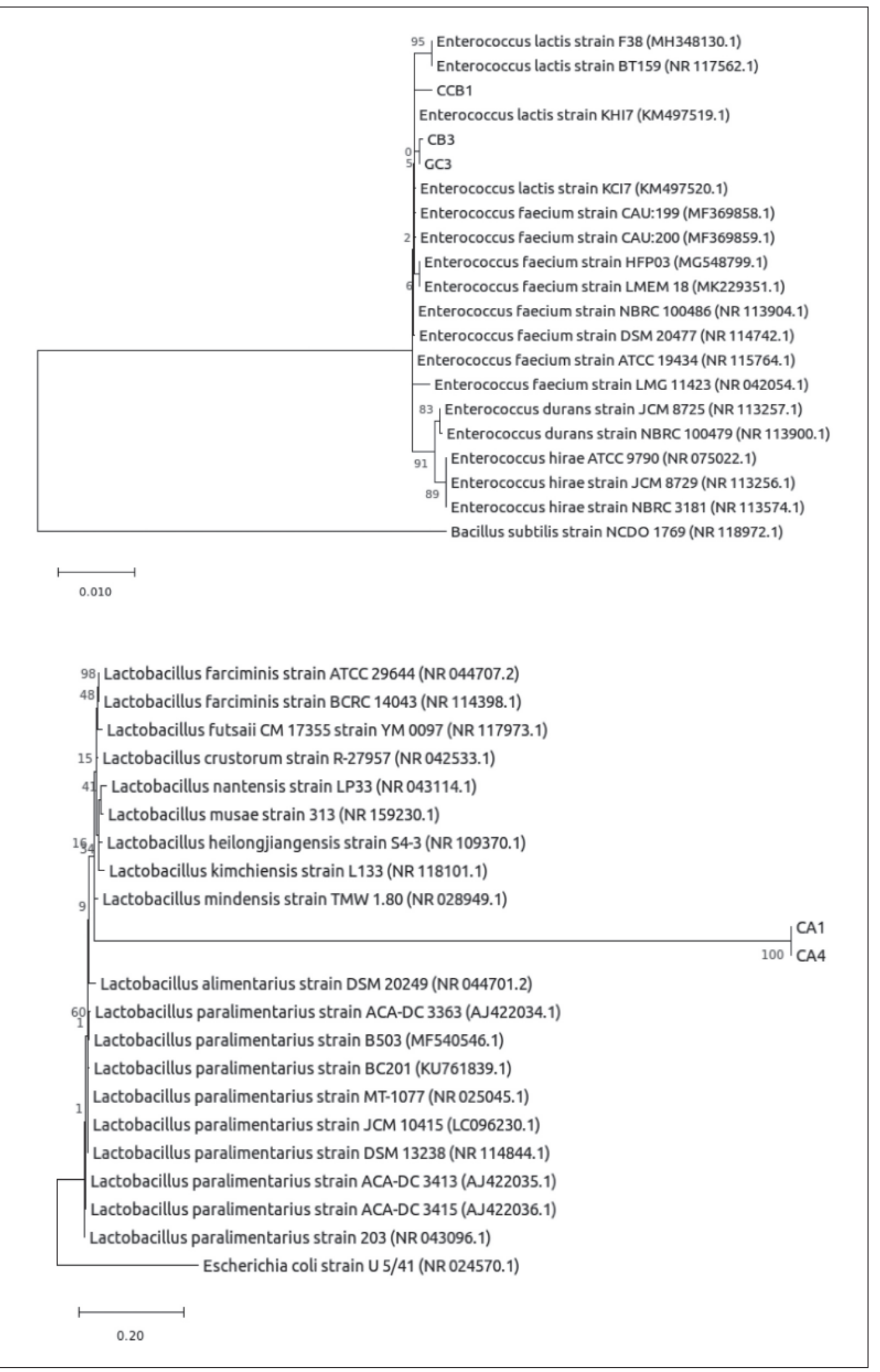

Fig. 1. Phylogenetic tree of five isolates and related taxa based on partial 16S rDNA sequences cut-off $1363 \mathrm{bp}$ (CCB1, GB3 and CB3) and 1521 bp (CA1 and CA4). The phylogenetic tree was inferred by using the Maximum Likelihood method and Kimura 2-parameter model (MEGA X 10.). The numbers at the nodes are books trap confidence levels from 1000 replicates. Escherichia coli strain U 5/41 and Bacillus subtilis NCDO 1769 were used as outgroup organism, respectively. (A) CCB1, GB3, CB3; (B) CA1 and CA4. 
Table 2. Growth of antimicrobial-producing $\mathrm{LAB}$ to $\mathrm{NaCl}$ and temperatures

\begin{tabular}{|c|c|c|c|c|}
\hline \multirow{3}{*}{ Strain } & \multicolumn{4}{|c|}{ Characteristics } \\
\hline & \multicolumn{2}{|c|}{ Range of $\mathrm{NaCl}(\%, w / v)$} & \multicolumn{2}{|c|}{ Range of temperature $\left({ }^{\circ} \mathrm{C}\right)$} \\
\hline & Minimum & Maximum & Minimum & Maximum \\
\hline CCB1 & 0.5 & 6.5 & 28 & 70 \\
\hline GB3 & 0.5 & 4.0 & 37 & 70 \\
\hline CB3 & 0.5 & 4.0 & 28 & 70 \\
\hline CA1 & 0.5 & 6.5 & -20 & 37 \\
\hline CA4 & 0.5 & 6.5 & -20 & 37 \\
\hline
\end{tabular}

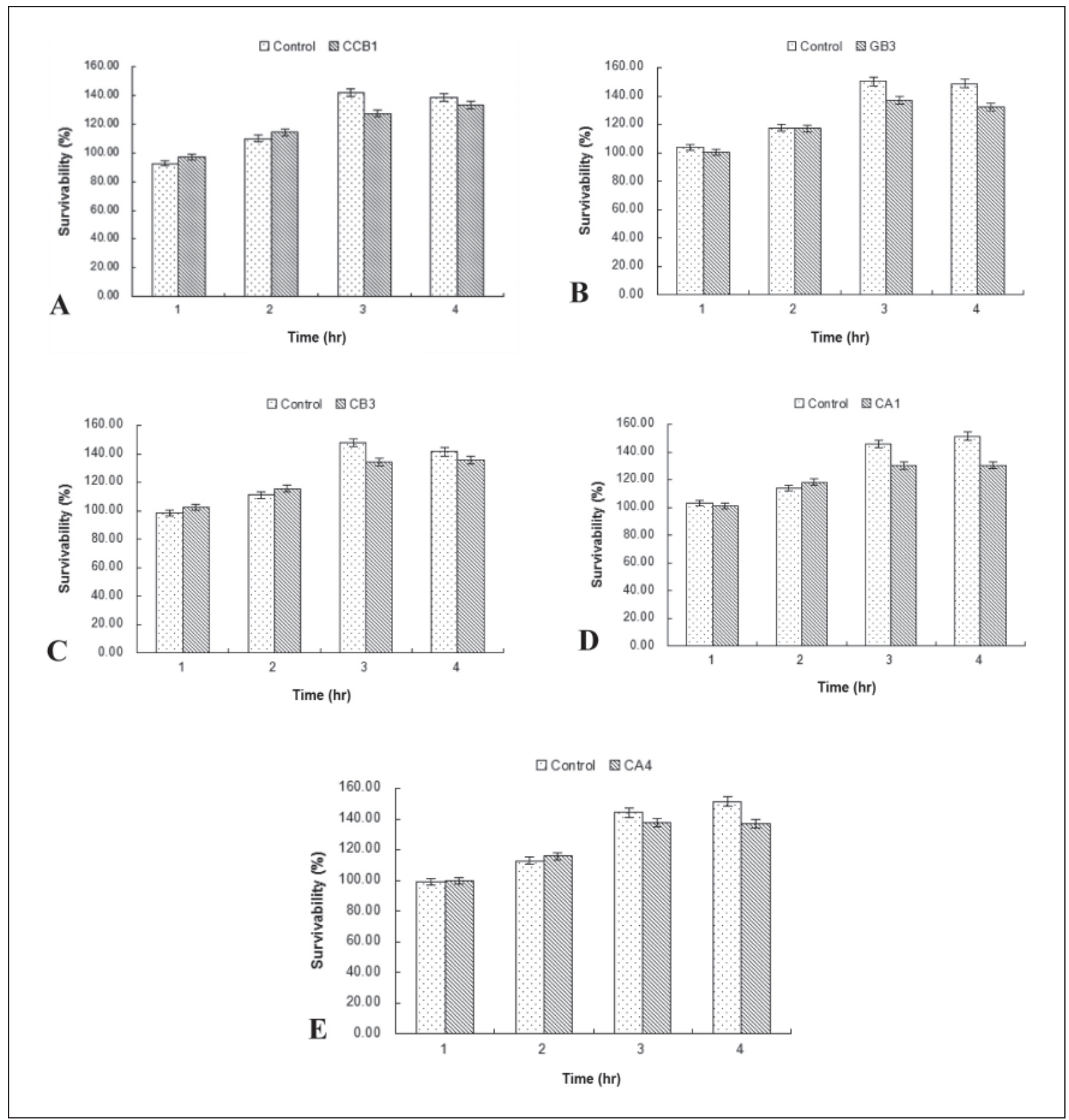

Fig. 2. Tolerance of selected five strains to bile salts. (A) CCB1; (B) GB3; (C) CB3; (D) CA1; (E) CA4; Control: MRS medium. 
Table 3. Effect of phenol on the growth of antimicrobial-producing $L A B$

\begin{tabular}{|c|c|c|c|c|}
\hline \multirow{3}{*}{ Strain } & \multirow{3}{*}{$\begin{array}{c}\text { MRS }+\%(w / v) \\
\text { of phenol }\end{array}$} & \multirow{2}{*}{\multicolumn{2}{|c|}{$\frac{\text { Viable count }\left(\log _{10} \mathrm{CFU} / \mathrm{mL}\right)}{\text { Time }}$}} & \multirow{3}{*}{$\begin{array}{l}\text { Growth } \\
\text { inhibition* }\end{array}$} \\
\hline & & & & \\
\hline & & $\mathrm{T}_{0}$ & $\mathrm{~T}_{24}$ & \\
\hline \multirow{4}{*}{ CCB1 } & 0 & $9.62 \pm 0.10$ & $10.26 \pm 0.74$ & -0.64 \\
\hline & 0.1 & $9.49 \pm 0.14$ & $9.59 \pm 0.03$ & -0.10 \\
\hline & 0.3 & $9.41 \pm 0.07$ & $9.83 \pm 0.18$ & -0.42 \\
\hline & 0.5 & $9.46 \pm 0.04$ & $9.77 \pm 0.08$ & -0.31 \\
\hline \multirow{4}{*}{ GB3 } & 0 & $9.56 \pm 0.02$ & $9.66 \pm 0.04$ & -0.11 \\
\hline & 0.1 & $9.67 \pm 0.14$ & $10.23 \pm 0.05$ & -0.56 \\
\hline & 0.3 & $9.36 \pm 0.03$ & $9.57 \pm 0.14$ & -0.21 \\
\hline & 0.5 & $9.5 \pm 0.08$ & $9.61 \pm 0.11$ & -0.11 \\
\hline \multirow{4}{*}{ CB3 } & 0 & $9.87 \pm 0.03$ & $9.89 \pm 0.03$ & -0.03 \\
\hline & 0.1 & $9.64 \pm 0.02$ & $10.42 \pm 0.06$ & -0.8 \\
\hline & 0.3 & $9.37 \pm 0.01$ & $9.63 \pm 0.3$ & -0.26 \\
\hline & 0.5 & $9.54 \pm 0.13$ & $9.60 \pm 0.08$ & -0.06 \\
\hline \multirow{4}{*}{ CA1 } & 0 & $9.63 \pm 0.04$ & $9.70 \pm 0.01$ & -0.07 \\
\hline & 0.1 & $10.36 \pm 0.05$ & $10.44 \pm 0.03$ & -0.1 \\
\hline & 0.3 & $9.38 \pm 0.08$ & $9.41 \pm 0.04$ & -0.03 \\
\hline & 0.5 & $9.37 \pm 0.07$ & $9.67 \pm 0.22$ & -0.30 \\
\hline \multirow{4}{*}{ CA4 } & 0 & $9.57 \pm 0.03$ & $9.63 \pm 0.03$ & -0.07 \\
\hline & 0.1 & $9.38 \pm 0.05$ & $9.96 \pm 0.09$ & -0.58 \\
\hline & 0.3 & $9.64 \pm 0.05$ & $9.96 \pm 0.04$ & -0.04 \\
\hline & 0.5 & $9.40 \pm 0.08$ & $9.79 \pm 0.10$ & -0.38 \\
\hline
\end{tabular}

Note: Inhibition ${ }^{*}=$ Average CFU/mL $\left(\mathrm{T}_{24}\right)-$ Average CFU/mL $\left(\mathrm{T}_{0}\right)$; Negative sign indicating no growth inhibition occur.

Table 4. Milk acidification activity of CCB1, GB3, CB3, CA1 and CA4

\begin{tabular}{|c|c|c|c|c|c|}
\hline \multirow{2}{*}{ Strain } & \multirow{2}{*}{$\begin{array}{l}\text { Incubation time } \\
\text { (hr) }\end{array}$} & \multirow{2}{*}{$\mathrm{pH}$} & \multicolumn{3}{|c|}{ Characteristics } \\
\hline & & & Curd appearance & Aroma & Colour \\
\hline \multirow{4}{*}{ CCB1 } & 0 & 6.65 & Runny & Flat & White \\
\hline & 24 & 4.59 & Coagulated & Foreign & Cream-white \\
\hline & 48 & 4.04 & Coagulated & Rancid & Cream-white \\
\hline & 72 & 3.87 & Coagulated & Rancid & Cream-white \\
\hline \multirow{4}{*}{ GB3 } & 0 & 6.52 & Runny & Flat & White \\
\hline & 24 & 4.38 & Coagulated & Foreign & Cream-white \\
\hline & 48 & 3.94 & Coagulated & Rancid & Cream-white \\
\hline & 72 & 3.78 & Coagulated & Rancid & Cream-white \\
\hline \multirow{4}{*}{ CB3 } & 0 & 6.77 & Runny & Flat & White \\
\hline & 24 & 4.67 & Coagulated & Foreign & Cream-white \\
\hline & 48 & 3.94 & Coagulated & Rancid & Cream-white \\
\hline & 72 & 3.81 & Coagulated & Rancid & Cream-white \\
\hline \multirow{4}{*}{ CA1 } & 0 & 6.75 & Runny & Flat & White \\
\hline & 24 & 4.54 & Coagulated & Foreign & Cream-white \\
\hline & 48 & 4.34 & Coagulated & Rancid & Cream-white \\
\hline & 72 & 4.18 & Coagulated & Rancid & Cream-white \\
\hline \multirow{4}{*}{ CA4 } & 0 & 6.37 & Runny & Flat & White \\
\hline & 24 & 5.14 & Coagulated & Foreign & Cream-white \\
\hline & 48 & 4.83 & Coagulated & Rancid & Cream-white \\
\hline & 72 & 4.60 & Coagulated & Rancid & Cream-white \\
\hline
\end{tabular}


Table 5. Antibiotic sensitivity testing of antimicrobial-producing LAB

\begin{tabular}{|c|c|c|c|c|c|c|}
\hline \multirow{2}{*}{ Antibiotic } & \multirow{2}{*}{$\begin{array}{c}\text { Disc } \\
\text { content }\end{array}$} & \multicolumn{5}{|c|}{ Inhibition zone diameter (mm) } \\
\hline & & CCB1 & GB3 & CB3 & CA1 & CA4 \\
\hline Ampicillin & $25 \mu \mathrm{g}$ & $27.75 \pm 0.35(\mathrm{~S})$ & $36.75 \pm 0.35(\mathrm{~S})$ & $37.50 \pm 0.71(\mathrm{~S})$ & $26.25 \pm 1.06(\mathrm{~S})$ & $34.0 \pm 1.41(\mathrm{~S})$ \\
\hline Amikacin & $30 \mu \mathrm{g}$ & $0(\mathrm{R})$ & $7.75 \pm 0.35(\mathrm{R})$ & $7.25 \pm 0.35(R)$ & $0(\mathrm{R})$ & $0(\mathrm{R})$ \\
\hline Ceftriaxone & $30 \mu \mathrm{g}$ & $29.0 \pm 1.41(\mathrm{~S})$ & $23.0 \pm 0.71(\mathrm{~S})$ & $20.75 \pm 1.06(\mathrm{~S})$ & $23.75 \pm 1.06(\mathrm{~S})$ & $32.25 \pm 1.06(\mathrm{~S})$ \\
\hline Chloramphenicol & $30 \mu \mathrm{g}$ & $36.75 \pm 0.35(\mathrm{~S})$ & $21.25 \pm 0.35(\mathrm{~S})$ & $20.75 \pm 1.06(S)$ & $19.50 \pm 0.71(\mathrm{I})$ & $25.5 \pm 1.06$ \\
\hline Colistin sulphate & $10 \mu \mathrm{g}$ & $0(\mathrm{R})$ & $0(\mathrm{R})$ & $0(\mathrm{R})$ & $0(\mathrm{R})$ & $0(\mathrm{R})$ \\
\hline Erythromycin & $10 \mu \mathrm{g}$ & $8.25 \pm 0.35(R)$ & $9.50 \pm 0.35(R)$ & $11.0 \pm 1.06(\mathrm{~S})$ & $10.75 \pm 1.06(R)$ & $0(\mathrm{R})$ \\
\hline Nalidixic acid & $30 \mu \mathrm{g}$ & $0(\mathrm{R})$ & $0(\mathrm{R})$ & $0(\mathrm{R})$ & $0(\mathrm{R})$ & $0(\mathrm{R})$ \\
\hline Norfloxacin & $10 \mu \mathrm{g}$ & $13.25 \pm 0.35(R)$ & $14.75 \pm 1.06(\mathrm{I})$ & $8.0 \pm 1.41(R)$ & $0(R)$ & $0(\mathrm{R})$ \\
\hline Penicillin G & 2 units & $30.0 \pm 0.71(\mathrm{~S})$ & $23.75 \pm 0.35(\mathrm{~S})$ & $22.75 \pm 1.06(\mathrm{~S})$ & $20.75 \pm 0.35$ (I) & $30.75 \pm 0.35(\mathrm{~S})$ \\
\hline Streptomycin & $10 \mu \mathrm{g}$ & $0(\mathrm{R})$ & $0(\mathrm{R})$ & $0(\mathrm{R})$ & $0(\mathrm{R})$ & $0(\mathrm{R})$ \\
\hline Tetracycline & $10 \mu \mathrm{g}$ & $0(\mathrm{R})$ & $30.0 \pm 0.35(\mathrm{~S})$ & $21.75 \pm 0.35(\mathrm{~S})$ & $14.75 \pm 0.35(R)$ & $0(\mathrm{R})$ \\
\hline
\end{tabular}

Note: Results of zone of inhibition are triplicate and expressed as Mean \pm S.D. Resistance $(\mathrm{R}) \leq 15 \mathrm{~mm}$; Intermediate (I) $16-20 \mathrm{~mm}$; Susceptible (S) $\geq 21 \mathrm{~mm}$.

inhibitory substances (BLIS) is very significant since bacteriocin plays the role to inhibit the growth of pathogens that can cause food spoilage (Mittu \& Girdhar, 2015). Many studies had been reported on the potential application of bacteriocin especially in the food industry.

Most of our strains are not tolerant in medium with more than $6.5 \%(\mathrm{w} / \mathrm{v})$ of $\mathrm{NaCl}$. This result is in line with the study conducted by Khedid et al. (2009), whereby the range of LAB growth is in between 2 to $6.5 \%(\mathrm{w} / \mathrm{v})$ and mostly inhibited at $10 \%(\mathrm{w} / \mathrm{v})$ of $\mathrm{NaCl}$ concentration. Tolerance of $\mathrm{NaCl}$ is important since some of the processes in food production involve exposure to high salt content and this subsequently will affect their food nutrient content (Ni et al., 2010). Some LAB are categorized either as thermophilic or mesophilic bacteria due to their ability to grow in different temperatures. The present study showed that CCB1, GB3 and CB3 are in a group of thermophilic bacteria since they are able to grow in $70^{\circ} \mathrm{C}$, while $\mathrm{CA} 1$ and CA4 could be considered to be psychrophilic bacteria as they are able to grow below $15^{\circ} \mathrm{C}$.

LAB can be considered as probiotic only if it has the characteristics including the ability to overcome the effect of bile salt and low environmental $\mathrm{pH}$ of gastrointestinal tract especially in human. In our study, the survivability of the five bacterial strains was in increasing pattern before the growth rate was reduced after $3 \mathrm{hr}$ of incubation (Figure 2). Bile salt plays a crucial role in terms of mechanism defence of intestinal tract. Hence, the bile tolerance of lactic acid bacteria is considered beneficial. Davati et al. (2015) reported that several isolates such as L. casei, E. durans, L. casei and P. pentosaceus isolated from raw camel milk exhibited high tolerance to bile salt $0.4 \%(\mathrm{w} / \mathrm{v})$ after being exposed for $6 \mathrm{hr}$. Moreover, all of the isolated strains are resistant to phenol at concentration of $0.1,0.3$ and $0.5 \%(\mathrm{w} / \mathrm{v})$. Present study is in line with the study carried out by Mannan et al. (2017) who found that $\mathrm{LAB}$ isolated from buffalo milk were tolerate to $0.1,0.3$ and $0.4 \%(\mathrm{w} / \mathrm{v})$ of phenol. Phenol is known as a toxic metabolite produced during the process of digestion in intestinal tract (Rowland et al., 2018). Hence, probiotic bacteria should be able to tolerate the phenol inside gastrointestinal tract of a host.

The ability in coagulating milk demonstrates the potential of LAB strains for application as a starter culture in the production of fermented products. All of the five isolated strains showed decrease in $\mathrm{pH}$ during the $72 \mathrm{hr}$ of incubation. The decrease in $\mathrm{pH}$ of skim milk revealed that these bacterial strains were able to act as the starter culture in milk fermentation due to their ability to produce acid, which is important in flavour enhancement; improve milk texture by producing exopolysaccharides and as preservative agents (Widyastuti \& Febrisiantosa, 2014). Additionally, the combination functions of antimicrobial substances such as organic acids with bacteriocins may be effective in preventing and inhibiting the growth of foodborne pathogen especially in fermented foods (Altuntas, 2013).

The hydrolysis of starch is the results of amylase enzyme activity. The ability of LAB to produce amylase is important as its potential could be applied in the food industry. Our results showed that most of the strain were positive in proteolytic activity (except CA1 and CA4). Similar study conducted by Donkor et al. (2007), who found that L. acidophilus, L. casei and S. thermophilus isolated from the dairy source also exhibited positive proteolytic activity. Bile salt deconjugation test is useful in order to understand the relationship 
between deconjugation of bile acid by probiotic strain and antibiotic susceptibility when there is a deconjugated bile acids present (He et al., 2012). In our study, 3 out of 5 strains were susceptible to ampicillin, tetracycline, ceftriaxone, penicillin $\mathrm{G}$ and chloramphenicol, but resistant to erythromycin, norfloxacin, amikacin, colistin sulphate, streptomycin and nalidixic acid. Gueimonde et al. (2013) stated that antibiotic resistant strain could transmit the resistance gene to the pathogenic microorganism inside gut microbiota. Moreover, probiotics also have the potential of carrying resistant genes that may be transferred to the other organisms as well as to the other LAB species (Sengupta \& Ghosh, 2015). The antibiotic resistance gene is transferred vertically between generations and increasing the survivability of resistant microbes (Tsang, 2017). Study conducted by Thumu and Halami (2012) stated that LAB, mostly from Enterococcus and Lactobacillus isolated from fermented food products have the resistance genes (tetM, tetL, tetO and tetK) for antibiotics namely erythromycin and tetracycline. Isolate CCB1 and GB3 also were highly resistant to collistion sulphate, streptomycin and nalidixic acid. In contrast with the study conducted by Shazali et al. (2014), the resistance of the LAB against streptomycin and nalidixic acid was highly significant.

\section{CONCLUSION}

Five antimicrobial-producing LAB coded as CCB1, GB3, CB3, CA1 and CA4 were successfully isolated from the local dairy products and raw milk. All these strains showed an inhibitory effect towards $L$. monocytogenes ATCC7644 and L. monocytogenes ATCC13932, also possessing probiotic properties and therefore possibly could be applied in food industry. In future, more intensive in vitro and in vivo assessments need to be carried out such as adhesion to the intestinal mucosa and development of effective delivery system of probiotics to the gastrointestinal tract.

\section{ACKNOWLEDGEMENT}

The authors would like to thank Faculty of Science and Natural Resources, Universiti Malaysia Sabah (UMS) for the facilities provided and to UMS for financial support under Fund Grant (SBK03842018).

\section{REFERENCES}

Abbasiliasi, S., Tan, J.S., Ibrahim, T.A.T., Ramanan, R.N., Vakhshiteh, F., Mustafa, S., Ling, T.C., Rahim, R.A. \& Ariff, A.B. 2012. Isolation of Pediococcus acidilactici Kp10 with ability to secrete bacteriocin-like inhibitory substance from milk products for applications in food industry. BMC Microbiology, 12(1): 260.

Alnakip, M.E., Mohamed, A.S., Kamal, R.M. \& Elbadry, S. 2016. Diversity of lactic acid bacteria isolated from raw milk in Elsharkia province, Egypt. Japanese Journal of Veterinary Research, 64 (Supplement 2): S23-S30. 49

Al-Sulaiman, F. 2000. Mechanical Properties of Date Palm Leaves. Journal of Reinforced Plastics and Composites, 19: 1379-1388. https://doi.org/10.1177/073168400772678491

Altuntas, E.G. 2013. Bacteriocins: A natural way to combat with pathogens. Microbial Pathogens and Strategies for Combating Them: Science, Technology and Education; Méndez-Vilas, A., Ed, 1007-1015.

Aranwela, N., Sanson, G. \& Read, J. 1999. Methods of assessing leaf-fracture properties. New Phytologist, 144: 369-393. https://doi.org/10. 1046/j.1469-8137.1999.00506.x

Ávila, A.F., Jesus, G.A.R., Mesania, A.A. \& Scari, A.S. 2007. Food mechanics: a new device for testign fruits and vegetables. Journal of the Brazilian Society of Mechanical Sciences and Engineering, 29(1): 1-6.

Bahnasawy, A.H., El-Haddad, Z.A., El-Ansary, M.Y. \& Sorour, H.M. 2004. Physical and mechanical properties of some Egyptian onion cultivars. Journal of Food Engineering, 62(3): 255-261. https://doi.org/10.1016/S0260-8774 (03)00238-3

Bourne, M.C. \& Comstock, S.H. 1981. Effect of Degree of Compression on Texture Profile Parameters. Journal of Texture Studies, 12(2): 201-216. https://doi.org/10.1111/j.1745-4603. 1981.tb01232.x

Brzozowski, L. \& Mazourek, M. 2018. A sustainable agricultural future relies on the transition to organic agro ecological pest management. Sustainability, 10(6): 2023.

Davati, N., Yazdi, F.T., Zibaee, S., Shahidi, F. \& Edalatian, M.R. 2015. Study of lactic acid bacteria community from raw milk of Iranian one humped camel and evaluation of their probiotic properties. Jundishapur Journal of Microbiology, 8(5). 
Desmet, M., Lammertyn, J., Van Linden, V., Verlinden, B.E., Darius, P. \& Nicolaï, B.M. 2004. The relative influence of stem and fruit properties on stem puncture injury in tomatoes. Postharvest Biology and Technology, 33: 101109. https://doi.org/10.1016/j.postharvbio. 2004.02.001

Desmet, M., Van Linden, V., Hertog, M.L.A.T.M., Verlinden, B.E., De Baerdemaeker, J. \& Nicolaï, B.M. 2004. Instrumented sphere prediction of tomato stem-puncture injury. Postharvest Biology and Technology, 34: 81-92. https://doi. org/10.1016/j.postharvbio.2004.04.006

Dinnella, C., Torri, L., Caporale, G. \& Monteleone, E. 2014. An exploratory study of sensory attributes and consumer traits underlying liking for and perceptions of freshness for ready to eat mixed salad leaves in Italy. Food Research International, 59: 108-116. https://doi.org/10. 1016/j.foodres.2014.02.009

Donkor, O.N., Henriksson, A., Vasiljevic, T. \& Shah, N.P. 2007. Proteolytic activity of dairy lactic acid bacteria and probiotics as determinant of growth and in vitro angiotensin-converting enzyme inhibitory activity in fermented milk. Le Lait, 87(1): 21-38.

El-Ziney, M.G. \& Debevere, J.M. 1998. The effect of reuterin on Listeria monocytogenes and Escherichia coli O157: $\mathrm{H} 7$ in milk and cottage cheese. Journal of Food Protection, 61(10): 1275-1280.

Emadi, B., Abbaspour-Fard, M.H. \& Kdv Yarlagadda, P. 2009. Mechanical properties of melon measured by compression, shear, and cutting modes. International Journal of Food Properties, 12(4): 780-790. https://doi.org/10.1080/ 10942910802056143

Emadi, Bagher, Kosse, V. \& Yarlagadda, P.K. 2005. Mechanical properties of pumpkin. International Journal of Food Properties, 8(2): $277-$ 287. https://doi.org/10.1081/JFP-200063044

Gemechu, T. 2015. Review on lactic acid bacteria function in milk fermentation and preservation. African Journal of Food Science, 9(4): 170-175.

Gilliland, S.E. \& Speck, M.L. 1977. Deconjugation of bile acids by intestinal lactobacilli. Applied and Environmental Microbiology, 33(1): 15-18.

Golmohammadi, A. 2013. Determination of mechanical properties of potato flesh during storage, 1273-1278.

Grotte, M., Duprat, F., Loonis, D. \& Piétri, E. 2001. Mechanical properties of the skin and the flesh of apples. International Journal of Food Properties, 4(1): 149-161. https://doi.org/10. 1081/JFP-100002193
Gueimonde, M., Sánchez, B., de los Reyes-Gavilán, C.G. \& Margolles, A. 2013. Antibiotic resistance in probiotic bacteria. Frontiers in Microbiology, 4: 202.

He, X., Zou, Y., Cho, Y. \& Ahn, J. 2012. Effects of bile salt deconjugation by probiotic strains on the survival of antibiotic-resistant foodborne pathogens under simulated gastric conditions. Journal of Food Protection, 75(6): 1090-1098.

Hiller, S. \& Jeronimidis, G. 1996. Fracture in potato tuber parenchyma. Journal of Materials Science, 31: 2779-2796. https://doi.org/10. 1007/bf00355984

Holt, C.B. 1970. Measurement of Tomato Firmness With a Universal Testing Machine. Journal of Texture Studies, 1(4): 491-501. https://doi.org/ 10.1111/j.1745-4603.1970.tb00747.x

Holt, J. \& Schoorl, D. 1977. Bruising and energy dissipation in apples. Journal of Textures Studies, 7: 421-432.

Holt, J.E. \& Schoorl, D. 1982. Mechanics of Failure in Fruits and Vegetables. Journal of Texture Studies, 13: 83-96. https://doi.org/10.1111/j. 1745-4603.1982.tb00879.x

Jackman, R.L. \& Stanley, D.W. 1994. Influence of the Skin on Puncture Properties of Chilled and Nonchilled Tomato Fruit. Journal of Texture Studies, 25(2): 221-230. https://doi.org/ 10.1111/j.1745-4603.1994.tb01328.x

Jensen, A. 2017. Baby Spinach Nutrition Information. Retrieved April 20, 2018, from https:// www.livestrong.com/article/557186-babyspinach-vs-lettuce/

Kays, S.J. 1991. Postharvest Physiology of Perishable Plant Products. New York: Van Nostrand Reinhold.

Khedid, K., Faid, M., Mokhtari, A., Soulaymani, A. \& Zinedine, A. 2009. Characterization of lactic acid bacteria isolated from the one humped camel milk produced in Morocco. Microbiological Research, 164(1): 81-91.

Linares, D.M., Gomez, C., Renes, E., Fresno, J.M., Tornadijo, M.E., Ross, R.P. \& Stanton, C. 2017. Lactic acid bacteria and bifidobacteria with potential to design natural biofunctional healthpromoting dairy foods. Frontiers Inmicrobiol, 8: 846.

Linares-Morales, J.R., Gutiérrez-Méndez, N., RiveraChavira, B.E., Pérez-Vega, S.B. \& NevárezMoorillón, G.V. 2018. Biocontrol processes in fruits and fresh produce, the use of lactic acid bacteria as a sustainable option. Frontiers in Sustainable Food Systems, 2: 50. 
Lucas, P.W., Choong, M.F., Tan, H.T.W., Turner, I.M. \& Berrick, A.J. 1991. The Fracture Toughness of the Leaf of the Dicotyledon Calophyllum inophyllum L. (Guttiferae). Philosophical Transactions of the Royal Society B: Biological Sciences, 334(January 2016): 95-106. https:// doi.org/10.1098/rstb.1991.0099

Mannan, S.J., Rezwan, R., Rahman, M.S. \& Begum, K. 2017. Isolation and biochemical characterization of Lactobacillus species from yogurt and cheese samples in Dhaka metropolitan area. Bangladesh Pharmaceutical Journal, 20(1): 27 33.

Masood, M.I., Qadir, M.I., Shirazi, J.H. \& Khan, I.U. 2011. Beneficial effects of lactic acid bacteria on human beings. Critical Reviews in Microbiology, 37(1): 91-98.

Mittu, B. \& Girdhar, Y. 2015. Role of lactic acid bacteria isolated from goat milk in cancer prevention. Autoimmun Infec Dis, 1(2): 24701025.

More, P.G., Kakade, A.S. \& Khodke, S.U. 2014. Mechanical Properties of Spinach. IOSR Journal of Agriculture and Veterinary Science, 7(4): 5761. https://doi.org/10.9790/2380-07415761

Nabil, S.A.N., Azam, M.M. \& Amer Eissa, A.H. 2012. Mechanical properties of tomato fruits under storage conditions. Journal of Applied Sciences Research, 8(JUNE 2012): 3053-3064. Retrieved from http://www.scopus.com/inward/ record.url?eid=2-s2.0-84865556397\&partner $\mathrm{ID}=40 \& \mathrm{md} 5=315 \mathrm{ca} 06 \mathrm{eb} 1 \mathrm{~b} 7 \mathrm{becd} 54535 \mathrm{fed} 45 \mathrm{c}$ $838 \mathrm{e} 4$

Nazir, Y., Hussain, S.A., Abdul Hamid, A. \& Song, Y. 2018. Probiotics and their potential preventive and therapeutic role for cancer, high serum cholesterol, and allergic and HIV diseases. BioMed Research International, 2018.

Newman, J.M., Hilton, H.W., Clifford, S.C. \& Smith, A.C. 2005. The mechanical properties of lettuce: A comparison of some agronomic and postharvest effects. Journal of Materials Science, 40: 1101-1104. https://doi.org/10. 1007/s10853-005-6923-3

Ni Mhurchu, C., Capelin, C., Dunford, E.K., Webster, J.L., Neal, B.C. \& Jebb, S.A. 2010. Sodium content of processed foods in the United Kingdom: analysis of 44,000 foods purchased by 21,000 households. The American Journal of Clinical Nutrition, 93(3): 594-600.

Perez, R.H., Zendo, T. \& Sonomoto, K. 2014. Novel bacteriocins from lactic acid bacteria (LAB): various structures and applications. In Microbial Cell Factories, 13(1). BioMed Central.
Perin, L.M. \& Nero, L.A. 2014. Antagonistic lactic acid bacteria isolated from goat milk and identification of a novel nisin variant Lactococcus lactis. BMC Microbiology, 14(1): 36.

Pucci, M.J., Vedamuthu, E.R., Kunka, B.S. \& Vandenbergh, P.A. 1988. Inhibition of Listeria monocytogenes by using bacteriocin PA-1 produced by Pediococcus acidilactici PAC 1.0. Applied and Environmental Microbiology, 54(10): 2349-2353.

Ragaert, P., Verbeke, W., Devlieghere, F. \& Debevere, J. 2004. Consumer perception and choice of minimally processed vegetables and packaged fruits. Food Quality and Preference, 15(3): 259-270. https://doi.org/10.1016/S09503293(03)00066-1

Read, J. \& Sanson, G.D. 2003. Characterizing sclerophylly: The mechanical properties of a diverse range of leaf types. New Phytologist, 160: 81-99. https://doi.org/10.1046/j.14698137.2003.00855.x

Reysenbach, A.L., Longnecker, K. \& Kirshtein, J. 2000. Novel bacterial and archaeal lineages from an in-situ growth chamber deployed at a Mid-Atlantic Ridge hydrothermal vent. Applied Environmental and Microbiology, 66: 3798806.

Rowland, I., Gibson, G., Heinken, A., Scott, K., Swann, J., Thiele, I. \& Tuohy, K. 2018. Gut microbiota functions: metabolism of nutrients and other food components. European Journal of Nutrition, 57(1): 1-24.

Sadrnia, H., Rajabipour, A., Jafari, A., Javadi, A., Mostofi, Y., Kafashan, J. \& De Baerdemaeker, J. 2008. Internal bruising prediction in watermelon compression using nonlinear models. Journal of Food Engineering, 86(2): 272-280. https://doi.org/10.1016/j.jfoodeng. 2007.10 .007

Sengupta, A. \& Ghosh, M. 2015. Reduction of cardiac and aortic cholesterol in hypercholesterolemic rats fed esters of phytosterol and omega-3 fatty acids. Journal of Food Science and Technology, 52(5): 2741-2750.

Shazali, N., Foo, H.L., Loh, T.C., Choe, D.W. \& Rahim, R.A. 2014. Prevalence of antibiotic resistance in lactic acid bacteria isolated from the faeces of broiler chicken in Malaysia. Gut Pathogens, 6(1): 1.

Shiu, J.W., Slaughter, D.C., Boyden, L.E. \& Barrett, D.M. 2015. Effect of the shear-to-compressive force ratio in puncture tests quantifying watermelon mechanical properties. Journal of Food Engineering, 150: 125-131. https://doi. org/10.1016/j.jfoodeng.2014.11.007 
Silberberg, M.S. 2000. The Molecular Nature of Matter and Change. 2nd Ed. McGraw Hill, Boston.

Tagg, J., Dajani, A. \& Wannamaker, L. 1976. Bacteriocins of gram-positive bacteria. Microbiology and Molecular Biology Reviews, 40: 722-756.

Tamura, K., Nei, M. \& Kumar, S. 2004. Prospects for inferring very large phylogenies by using the neighbour-joining method. Proceedings of the National Academy of Sciences (USA), 101: 11030-35.

Tang, X., Mo, C.Y., Chan, D.E., Peng, Y., Qin, J., Yang, C.-C. \& Chao, K. 2011. Physical and mechanical properties of spinach for wholesurface online imaging inspection. Moon, 8027: 802711-802719. https://doi.org/10.1117/12. 884892

Thumu, S.C.R. \& Halami, P.M. 2012. Presence of erythromycin and tetracycline resistance genes in lactic acid bacteria from fermented foods of Indian origin. Antonie Van Leeuwenhoek, 102(4): 541-551.

Thybo, A.K. \& Nielsen, M. 2000. Influence of uniaxial compression rate on rheological parameters and sensory texture prediction of cooked potatoes. Journal of Texture Studies, 31(1): 25-40. Retrieved from file://reinette/bdd/ BaseBiblio/Photocopies/10208.pdf

Toole, G.A., Parker, M.L., Smith, A.C. \& Waldron, K.W. 2000. Mechanical properties of lettuce. Journal of Materials Science, 35: 3553-3559. https://doi.org/10.1023/A:1004809428967
Toole, Geraldine A., Gunning, P.A., Parker, M.L., Smith, A.C. \& Waldron, K.W. 2001. Fracture mechanics of the cell wall of Chara corallina. Planta, 212(July 2000): 606-611. https://doi. org/10.1007/s004250000425

Tro, N.J. 2008. A Molecular Approach. 1st Ed. Pearson Prentice Hall, Upper Saddle River.

Tsang, J. 201__. Bacterial plasmid addiction systems and their implications for antibiotic drug development. Postdoc Journal: A Journal of Postdoctoral Research and Postdoctoral Affairs, 5(5): 3.

Vincent, J.F.V. 1991. Strength and fracture of grasses. Journal of Materials Science, 26: $1947-$ 1950. https://doi.org/10.1007/BF00543628

Vincent. \& Julian, F.V. 1982. The mechanical design of grass. Journal of Materials Science, 17: 856860. https://doi.org/10.1007/BF0054 0384

Wang, S., Ren, L., Liu, Y., Han, Z. \& Yang, Y. 2010. Mechanical characteristics of typical plant leaves. Journal of Bionic Engineering, 7: 294300. https://doi.org/10.1016/S1672-6529(10) 60253-3

Widyastuti, Y. \& Febrisiantosa, A. (2014). The role of lactic acid bacteria in milk fermentation. Food and Nutrition Sciences, 5(4): 720-726.

Yang, S.C., Lin, C.H., Sung, C.T. \& Fang, J.Y. 2014. Antibacterial activities of bacteriocins: application in foods and pharmaceuticals. Frontiers in Microbiology, 5: 241.

Zhu, H.X. \& Melrose, J.R. 2003. A mechanics model for the compression of plant and vegetative tissues. Journal of Theoretical Biology, 221(1): 89-101. https://doi.org/10. 1006/jtbi.2003.3173 